\title{
Marginal bone loss in relation to the implant neck surface: An update
}

\author{
Amparo Aloy-Prósper ${ }^{1}$, Laura Maestre-Ferrín ${ }^{2}$, David Peñarrocha-Oltra ${ }^{1}$, María Peñarrocha-Diago ${ }^{3}$ \\ ${ }^{1}$ Degree in Dentistry. Resident in the Master of Oral Surgery and Implantology. Faculty of Medicine and Dentistry. University \\ of Valencia \\ ${ }^{2}$ Master of Oral Surgery and Implantolgy. Faculty of Medicine and Dentistry. University of Valencia \\ ${ }^{3}$ Associate Professor of Oral Surgery. Faculty of Medicine and Dentistry. University of Valencia
}

Correspondence:

Clínicas odontológicas

Gascó Oliag 1

46021 - Valencia (Spain)

maria.penarrocha@uv.es

Received: $11 / 03 / 2010$

Accepted: $26 / 08 / 2010$

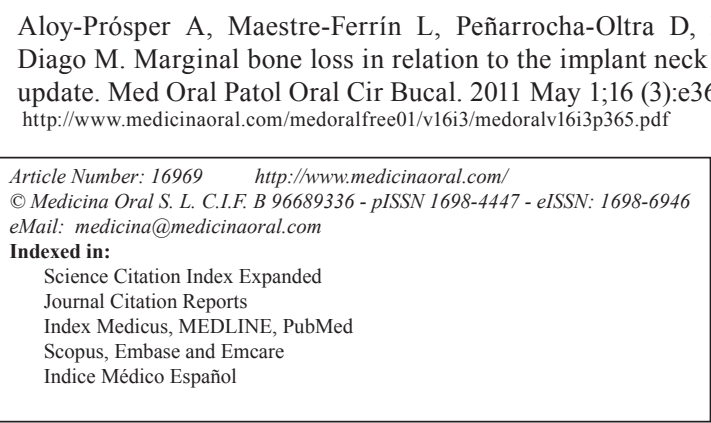

\begin{abstract}
A review is made of the publications on the marginal bone loss of implants with a polished neck, rough neck with microthreading, and rough neck without microthreading.

A PubMed search was carried out with the following key words: machined neck implant, polished neck implant, marginal bone loss, covering the period between January 1998 and March 2009. Inclusion was limited to those human clinical studies involving a minimum follow-up of 12 months, and registering the level of bone loss from the time of placement of the implant or prosthetic restoration to the end of follow-up.

For most of the authors there were no significant differences in marginal bone loss between polished neck and rough neck implants. On the other hand, implants with a rough neck and microthreading showed significantly less bone loss than those with a polished neck or with a rough neck without microthreading. The survival rate of the implants with a polished neck ranged from $87 \%$ to $97.7 \%$, versus $94.5 \%$ to $100 \%$ for those with a rough neck, and $100 \%$ for the rough neck implants with microthreading. No peri-implant disease was registered in the different studies.
\end{abstract}

Key words: Dental implants, polished neck, machined neck, rough neck, bone loss.

\section{Introduction}

Marginal bone loss is observed after dental implant placement $(1,2)$. This loss begins at the neck of the implant and spreads to the first thread of the body of the implant or to the first contact between the bone and the rough surface of the implant (3). Peri-implant bone reabsorption depends on a number of factors such as the surface of the neck (1-10) and reduction of the implant platform (11-13). There is no agreement regarding the influence of performing surgery in one or two steps (1416) or of the cylindrical or conical morphology of the neck $(3,4)$.

The present article analyzes the publications related to the marginal bone loss of implants according to the implant neck surface involved (i.e., polished neck and rough neck with or without microthreading), and evalu- 
ates marginal bone loss associated with the different types of neck, the survival rate of the implants, and the possible complications associated to their morphology.

\section{Inclusion criteria and search strategy}

A literature review was carried out covering the period between January 1998 and March 2009 relating to the bone loss of implants with a polished neck and with a rough neck. Inclusion was limited to those human clinical studies involving a minimum follow-up of 12 months, and registering the level of bone loss from the time of placement of the implant or prosthetic restoration to the end of follow-up.

A PubMed search was carried out with the following key words: machined neck implant, polished neck implant, marginal bone loss. Articles were included from the following journals: The International Journal of Oral and Maxillofacial Implants, Clinical Oral Implants Research, Journal of Oral Rehabilitation, Journal of Periodontology, Journal of Oral and Maxillofacial Surgery, Clinical Implant Dentistry and Related Research.
A total of 33 articles were found, of which 23 were excluded: 5 reviews, 4 studies in animals, 2 studies with a follow-up of under 12 months, and 12 papers failing to report data on bone loss from the time of placement of the implant or of the prosthetic restoration to the end of follow-up. Ten studies were thus finally considered ( Table 1), with collection of the following data from each of them: year of publication, type of study; type of implant neck, number of implants, duration of follow-up, and results.

Three study groups were established: implants with a polished neck, implants with a rough neck without microthreading, and implants with a rough neck and microthreading. In all the reviewed studies the implants were placed at bone crest level. All the authors measured bone loss from the start of prosthetic loading to the end of follow-up, except Nickening et al. (6), who measured loss from the time of placement of the implants.

Not all the studies compared implants differentiated only according to the neck surface involved, since comparisons were also made of different commercial brands

Table 1. Summary of studies reviewed.

\begin{tabular}{|c|c|c|c|c|c|c|}
\hline $\begin{array}{l}\text { Author } \\
\text { (year) }\end{array}$ & $\begin{array}{l}\text { Type of } \\
\text { study }\end{array}$ & $\begin{array}{c}\text { Neck implant } \\
\text { surface }\end{array}$ & $\begin{array}{c}\text { No. } \\
\text { implants }\end{array}$ & $\begin{array}{c}\text { Implant } \\
\text { survival rate } \\
(\%)\end{array}$ & $\begin{array}{c}\text { Follow- } \\
\text { up } \\
\text { (months) }\end{array}$ & $\begin{array}{l}\text { Differences in } \\
\text { marginal bone } \\
\text { loss between } \\
\text { groups }\end{array}$ \\
\hline \multirow{2}{*}{$\begin{array}{c}\text { Karlsson et } \\
\text { al } \\
(1998)\end{array}$} & \multirow[b]{2}{*}{ Prospective } & Polished & 64 & 95,3 & \multirow[b]{2}{*}{24} & \multirow[b]{2}{*}{ Non significative } \\
\hline & & Rough & 64 & 100 & & \\
\hline $\begin{array}{l}\text { Norton } \\
\text { (1998) }\end{array}$ & Retrospective & $\begin{array}{c}\text { Rough }+ \\
\text { microthreading }\end{array}$ & 33 & 100 & $6-48$ & - \\
\hline \multirow{2}{*}{$\begin{array}{c}\text { Astrand y } \\
\text { Karlsson } \\
\text { (1999) }\end{array}$} & \multirow{2}{*}{ Prospective } & Polished & 187 & 95,7 & \multirow{2}{*}{12} & \multirow{2}{*}{ Non significative } \\
\hline & & Rough & 184 & 99,5 & & \\
\hline \multirow{2}{*}{$\begin{array}{l}\text { Puchades- } \\
\text { Roman et } \\
\text { al. (2000) }\end{array}$} & \multirow[b]{2}{*}{ Prospective } & Polished & 15 & - & \multirow[b]{2}{*}{$\geq 24$} & \multirow[b]{2}{*}{ Significative } \\
\hline & & $\begin{array}{c}\text { Rough }+ \\
\text { microthreading }\end{array}$ & 15 & - & & \\
\hline \multirow{2}{*}{$\begin{array}{c}\text { Van } \\
\text { Steenberghe } \\
\text { et al. (2000) }\end{array}$} & \multirow{2}{*}{ Prospective } & Polished & 45 & 97,7 & \multirow{2}{*}{24} & \multirow[t]{2}{*}{ Significative } \\
\hline & & Rough & 30 & 100 & & \\
\hline \multirow{2}{*}{$\begin{array}{c}\text { Hallman et } \\
\text { al. } \\
(2005)\end{array}$} & \multirow[b]{2}{*}{ Prospective } & Polished & 84 & 87 & \multirow[b]{2}{*}{60} & \multirow[b]{2}{*}{ Non significative } \\
\hline & & Rough & 72 & 94,5 & & \\
\hline \multirow{2}{*}{$\begin{array}{l}\text { Lee et al. } \\
\text { (2007) }\end{array}$} & \multirow[b]{2}{*}{$\begin{array}{l}\text { Prospective } \\
\text { Randomized } \\
\text { Split-mouth }\end{array}$} & Rough & 17 & 100 & \multirow[b]{2}{*}{36} & \multirow[b]{2}{*}{ Significative } \\
\hline & & $\begin{array}{c}\text { Rough }+ \\
\text { microthreading }\end{array}$ & 17 & 100 & & \\
\hline \multirow{2}{*}{$\begin{array}{l}\text { Bratu et al. } \\
\text { (2009) }\end{array}$} & \multirow[b]{2}{*}{ Prospective } & Polished & 46 & 100 & \multirow[b]{2}{*}{12} & \multirow{2}{*}{ Significative } \\
\hline & & $\begin{array}{c}\text { Rough }+ \\
\text { microthreading }\end{array}$ & 46 & 100 & & \\
\hline \multirow{2}{*}{$\begin{array}{l}\text { Nickening } \\
\text { et al. (2009) }\end{array}$} & \multirow{2}{*}{$\begin{array}{l}\text { Prospective } \\
\text { Split-mouth }\end{array}$} & Polished & 63 & 100 & \multirow{2}{*}{12} & \multirow[t]{2}{*}{ Significative } \\
\hline & & Rough & 70 & 100 & & \\
\hline \multirow{2}{*}{$\begin{array}{l}\text { Piao et al. } \\
\text { (2009) }\end{array}$} & \multirow{2}{*}{ Prospective } & Polished & 61 & 100 & \multirow{2}{*}{12} & \\
\hline & & Rough & 62 & 100 & & Non significative \\
\hline & & Polished & 61 & 100 & & \\
\hline (2009) & Prospective & $\begin{array}{c}\text { Rough }+ \\
\text { microthreading }\end{array}$ & 66 & 100 & 12 & Significative \\
\hline
\end{tabular}


(7-9) or different connecting morphologies between the implant and the abutment $(3,4)$. Comparisons and conclusions were thus difficult to establish. Lee et al. (3) compared cylindrical polished neck implants versus conical rough neck implants with microthreading - a fact that may have affected the results obtained.

\section{Results \\ -Bone loss \\ Polished neck versus rough neck without microthread- ing}

In the studies published by Van Steenberghe et al. (9) and Nickening et al. (6), significantly greater bone loss was recorded with the polished neck implants versus the rough neck implants after one and two years of followup, respectively. Van Steenberghe et al. (9) in turn recorded a bone loss of $2.3 \pm 0.6 \mathrm{~mm}$ for polished neck implants and $1.66 \pm 0.3 \mathrm{~mm}$ for rough neck implants. In the study of Nickening et al. (6), the bone loss values for the implants with a smooth neck were $0.5 \mathrm{~mm}, 0.8 \mathrm{~mm}$ and $1.1 \mathrm{~mm}$ after 3, 6 and 24 months, respectively, while in the group of rough neck implants with microthreading the values were $0.1 \mathrm{~mm}, 0.4 \mathrm{~mm}$ and $0.5 \mathrm{~mm}$ after 3,6 and 24 months, respectively.

In contrast, other authors such as Karlsson et al. (17), Astrand et al. (2), Hallman et al. (18) and Piao et al. (4) found no statistically significant differences in bone loss.

It is not clear whether a rough neck without microthreading reduces bone loss compared with a polished neck - though most authors have recorded no statistically significant differences between the two types.

In 1998, Brägger et al. (19), inserted implants at supracrestal level in order to eliminate the possible influence of the polished neck upon bone loss. After one year of follow-up, they recorded a bone loss of $0.78 \mathrm{~mm}$, and concluded that a rough surface was not sufficient to avoid crestal bone loss - though the mentioned study did not meet the inclusion criteria of our review.

Polished neck versus rough neck with microthreading Puchades-Roman et al. (8), Bratu et al. (10) and Piao et al. (4) observed statistically significant differences between polished neck implants and rough neck implants with microthreading, after a minimum follow-up of one year. Puchades-Roman et al. (8) in turn compared 15 polished neck implants with 15 rough neck implants with microthreading - recording bone loss values of $1.6 \mathrm{~mm}$ and $0.6 \mathrm{~mm}$, respectively. Bratu et al. (10), in their study of 46 polished neck implants and 46 rough neck implants with microthreading, reported a bone loss of $0.69 \pm 0.25 \mathrm{~mm}$ in the rough neck implants versus $1.47 \pm 0.4 \mathrm{~mm}$ with the polished neck implants. According to Piao et al. (4), the bone loss was $0.89 \pm 0.27$ with the polished neck implants and $0.42 \pm 0.27$ in the case of the rough neck implants with microthreading.
According to these authors $(4,8,10)$, microthreading of the implant neck could contribute to preserve marginal bone.

Rough neck versus rough neck with microthreading Norton (5) studied 33 implants with a rough neck and microthreading, and after four years of follow-up the bone loss values were $0.3 \mathrm{~mm}$ mesial and $0.34 \mathrm{~mm}$ distal. According to Lee et al. (3) and Piao et al. (4), the differences in bone loss between implants with a rough neck and microthreading versus a rough neck without microthreading were statistically significant. Lee et al. (3) recorded a bone loss of $0.28 \mathrm{~mm}$ with rough neck implants versus $0.14 \mathrm{~mm}$ with microthread implants, after one year of follow-up. According to Piao et al. (4), bone loss was $0.81 \pm 0.27 \mathrm{~mm}$ in the case of rough neck implants without microthreading and $0.42 \pm 0.27 \mathrm{~mm}$ in the case of microthread implants. In the opinion of these authors (3-5), microthreading of the neck of the implant could reduce marginal bone loss.

In all the reviewed studies, marginal bone loss with polished neck implants was greater three months after implant placement, while bone loss with rough neck implants with and without microthreading was greater 6 months after insertion of the implants. In the studies involving a follow-up of over year $(3,8,9,17,18)$, the greatest bone loss was seen to occur during the first year, and then gradually decreased.

\section{-Survival rate}

The survival rate of the polished neck implants ranged from $87 \%(18)$ to $100 \%(4,6,10)$. In the case of the rough neck implants without microthreading, the survival rate varied from $94.5 \%$ (18) to $100 \%(3,4,6,9,17)$. Lastly, in the rough neck implants with microthreading, the survival rate was found to be $100 \%(3-5,10)$.

\section{-Complications}

According to Cosyn et al. (20), rough neck implants favor bacterial plaque retention when exposed to the oral environment. This in turn would imply an increased risk of peri-implant disease such as mucositis or periimplantitis $(19,20)$. However, none of the reviewed studies reported disorders of this kind.

\section{Conclusion}

The incorporation of microthreading to rough neck implants has led to minimal marginal bone loss over follow-up.

\section{References}

References with links to Crossref-DOI

1. Peñarrocha M, Palomar M, Sanchis JM, Guarinos J, Balaguer J. Radiologic study of marginal bone loss around 108 dental implants and its relationship to smoking, implant location, and morphology. Int J Oral Maxillofac Implants. 2004;19:861-7.

2. Astrand P, Engquist B, Dahlgren S, Gröndahl K, Engquist E, Feldmann H. Astra Tech and Brånemark system implants: a 5-year prospective study of marginal bone reactions. Clin Oral Implants Res. 2004; 15:413-20. 
3. Lee DW, Choi YS, Park KH, Kim CS, Moon IS. Effect of microthread on the maintenance of marginal bone level: a 3-year prospective study. Clin Oral Implants Res. 2007;18:465-70.

4. Piao CM, Lee JE, Koak JY, Kim SK, Rhyu IC, Han CH, et al. Marginal bone loss around three different implant systems: radiographic evaluation after 1 year. J Oral Rehabil. 2009;36:748-54.

5. Norton MR. Marginal bone levels at single tooth implants with a conical fixture design. The influence of surface macro- and microstructure. Clin Oral Implants Res. 1998;9:91-9.

6. Nickenig HJ, Wichmann M, Schlegel KA, Nkenke E, Eitner S. Radiographic evaluation of marginal bone levels adjacent to parallelscrew cylinder machined-neck implants and rough-surfaced microthreaded implants using digitized panoramic radiographs. Clin Oral Implants Res. 2009;20:550-4.

7. Astrand P, Engquist B, Dahlgren S, Engquist E, Feldmann H, Gröndahl K. Astra Tech and Brånemark System implants: a prospective 5-year comparative study. Results after one year. Clin Implant Dent Relat Res. 1999;1:17-26.

8. Puchades-Roman L, Palmer RM, Palmer PJ, Howe LC, Ide M, Wilson RF. A clinical, radiographic, and microbiologic comparison of Astra Tech and Brånemark single tooth implants. Clin Implant Dent Relat Res. 2000;2:78-84.

9. Van Steenberghe D, De Mars G, Quirynen M, Jacobs R, Naert I. A prospective

split-mouth comparative study of two screw-shaped self-tapping pure titanium implant systems. Clin Oral Implants Res. 2000;11:202-9.

10. Bratu EA, Tandlich M, Shapira L. A rough surface implant neck with microthreads reduces the amount of marginal bone loss: a prospective clinical study. Clin Oral Implants Res. 2009;20:827-32.

11. Hürzeler M, Fickl S, Zuhr O, Wachtel HC. Peri-implant bone level around implants with platform-switched abutments: preliminary data from a prospective study. J Oral Maxillofac Surg. 2007;65:33-9.

12. Prosper L, Redaelli S, Pasi M, Zarone F, Radaelli G, Gherlone EF. A randomized prospective multicenter trial evaluating the platform-switching technique for the prevention of postrestorative crestal bone loss. Int J Oral Maxillofac Implants. 2009;24:299-308.

13. Vigolo P, Givani A. Platform-switched restorations on widediameter implants: a 5-year clinical prospective study. Int J Oral Maxillofac Implants. 2009;24:103-9.

14. Astrand P, Engquist B, Anzén B, Bergendal T, Hallman M, Karlsson $U$, et al. Nonsubmerged and submerged implants in the treatment of the partially edentulous maxilla. Clin Implant Dent Relat Res. 2002;4:115-27.

15. Cecchinato D, Bengazi F, Blasi G, Botticelli D, Cardarelli I, Gualini F. Bone level alterations at implants placed in the posterior segments of the dentition: outcome of submerged/non-submerged healing. A 5-year multicenter, randomized, controlled clinical trial. Clin Oral Implants Res. 2008;19:429-31.

16. Cecchinato D, Olsson C, Lindhe J. Submerged or non-submerged healing of endosseous implants to be used in the rehabilitation of partially dentate patients. J Clin Periodontol. 2004;31:299-308.

17. Karlsson U, Gotfredsen K, Olsson C. A 2-year report on maxillary and mandibular fixed partial dentures supported by Astra Tech dental implants. A comparison of 2 implants with different surface textures. Clin Oral Implants Res. 1998;9:235-42.

18. Hallman M, Mordenfeld A, Strandkvist T. A retrospective 5-year follow-up study of two different titanium implant surfaces used after interpositional bone grafting for reconstruction of the atrophic edentulous maxilla. Clin Implant Dent Relat Res. 2005;7:121-6.

19. Brägger U, Häfeli U, Huber B, Hämmerle CH, Lang NP. Evaluation of postsurgical crestal bone levels adjacent to non-submerged dental implants. Clin Oral Implants Res. 1998;9:218-24.

20. Cosyn J, Sabzevar MM, De Wilde P, De Rouck T. Two-piece implants with turned versus microtextured collars. J Periodontol. 2007;78:1657-63. 